\title{
Synergistic Effect of Carboplatin and Piroxicam on Two Bladder Cancer Cell Lines
}

\author{
JÉSSICA SILVA ${ }^{1 *}$, REGINA ARANTES-RODRIGUES $^{2,3^{*}}$, ROSÁRIO PINTO-LEITE $^{3,4}$, \\ ANA I. FAUSTINO-ROCHA ${ }^{2,5}$, LIO FIDALGO-GONÇALVES ${ }^{6}$, LÚCIO SANTOS ${ }^{4,7,8}$ and PAULA A. OLIVEIRA ${ }^{1,2}$ \\ ${ }^{1}$ Department of Veterinary Sciences, \\ ${ }^{2}$ Center for the Research and Technology of Agro-Environmental and Biological Sciences (CITAB), \\ ${ }^{3}$ Cytogenetic Laboratory, Hospital Center of Trás-os-Montes and Alto Douro, Vila Real, Portugal; \\ ${ }^{4}$ Experimental Pathology and Therapeutics Group, and ${ }^{8}$ Medical Oncology Department, \\ Portuguese Institute of Oncology, Porto, Portugal; \\ ${ }^{5}$ Faculty of Veterinary Medicine, Lusophone University of Humanities and Technologies, Lisbon, Portugal; \\ ${ }^{6}$ Institute for Systems and Computer Engineering, Technology and Science (INESC-TEC), \\ University of Trás-os-Montes and Alto Douro, Vila Real, Portugal; \\ ${ }^{7}$ Health School, University Fernando Pessoa, Porto, Portugal
}

\begin{abstract}
Background/Aim: This study aimed to evaluate the in vitro efficacy of carboplatin and piroxicam, both in isolation and combined, against T24 and 5637 human urinary bladder cancer cell lines. Materials and Methods: Cell viability, drug interaction, cell morphology, cell proliferation, apoptosis and autophagy were analyzed after $72 h$ of drug exposure. Statistical analysis was performed and values of $p<0.05$ were considered statistically significant. Results: Drug exposure in combination led to a significant reduction of cell viability comparatively to single-drug exposure. These combinations resulted in a synergistic interaction in the T24 (combination index for $50 \%$ effect $\left(C_{50}\right)=0.65$ ) and $5637\left(\mathrm{CI}_{50}=0.17\right)$ cell lines. Notable increase of morphological alterations, a marked decrease of Ki-67 expression, a considerable enhancement of autophagic vacuoles and a minimal effect on apoptosis was observed in both cell lines treated with combined drugs. Conclusion: Data showed that in vitro combination of carboplatin and piroxicam produced a more potent antiproliferative effect when compared to single drugs.
\end{abstract}

\footnotetext{
*These Authors contributed equally to this study.

Correspondence to: Paula A. Oliveira, CITAB, Department of Veterinary Sciences, University of Trás-os-Montes and Alto Douro, 5001-911, Vila Real, Portugal. E-mail: pamo@utad.pt
}

Key Words: Carboplatin, piroxicam, synergistic effect, urinary bladder cancer cell lines.
Urinary bladder cancer is considered the most expensive cancer to treat and its incidence and mortality have not decreased in the past three decades (1). It is the fourth most frequent cancer among men in Europe, with a 3-fold higher incidence when compared to women (2). The etiology of this neoplasia appears to be multifactorial, with both exogenous environmental factors and endogenous molecular factors playing possible roles (3).

Cisplatin-based chemotherapy is widely used in treatment of urinary bladder cancer, but approximately $50 \%$ of patients with this kind of cancer are not eligible for cisplatin-based standard chemotherapy due to impaired renal function $(4,5)$. However, no standard chemotherapy has been established for those patients (6). Although platinum drugs remain a critical component of chemotherapy in this type of cancer, cumulative toxicities can limit their use (7). Carboplatin is a second-generation platinum compound and an alkylating anticancer drug widely used as an alternative to cisplatin chemotherapy in unfit patients due to its reduced nephrotoxicity $(6,8,9)$.

Recently, several reports have emerged suggesting that the efficacy of conventional anticancer agents can be enhanced by their use in combination with cyclo-oxygenase (COX) inhibitors (10-13). COX inhibitors, widely applied for the treatment of inflammation, are considered as hopeful compounds for prevention and treatment of many neoplasias. $\mathrm{COX}$ is an important enzyme that catalyzes the conversion of arachidonic acid into prostaglandin and several investigations have shown that a variety of tumors, including urinary bladder cancer, produce greater amounts of prostaglandins when compared to the normal tissue from which they were derived (14-16). Two COX isoforms are 
well recognized: COX1 is constitutively expressed in most tissues and regulates multiple physiologic processes, whereas COX2 is associated with carcinogenesis, given that it is expressed in several malignant tumor types $(16,17)$. Piroxicam is a non-steroidal anti-inflammatory drug that blocks the activity of both COX1 and COX2 (18). It is used for treatment of osteoarthritis and also found to be effective in the treatment of urinary bladder transitional cell carcinoma and oral squamous cell carcinoma in $\operatorname{dog} s(19,20)$, as well as in the treatment of inflammatory mammary carcinoma in dogs (21). Despite this, data concerning its effectiveness in models of human urinary bladder are still lacking.

This study aimed to evaluate the in vitro efficacy of carboplatin and piroxicam, both in isolation and combined, against T24 and 5637 human urinary bladder cancer cell lines.

\section{Materials and Methods}

Chemicals. RPMI-1640 culture medium and trypsin were purchased from PAA Laboratories (Pasching, Austria). Fetal bovine serum, penicillin and streptomycin were obtained from Biological Industries (Kibbutz Beit Haemek, Israel). L-Glutamine and dimethylsulfoxide were provided by Sigma Aldrich (St. Louis, MO, USA). Carboplatin was acquired from TEVA (Porto Salvo, Portugal) and piroxicam was obtained from Menarini (Oeiras, Portugal). 3(4,5-Dimethyl-2-thiazolyl)-2,5-diphenyltetrazolium bromide (MTT) was purchased from Sigma Aldrich. Fluorescein In Situ Cell Death Detection Kit was acquired from Roche (Indianapolis, IN, USA). Primary antibody to Ki-67 was purchased from Dako (Glostrup, Denmark) and 3,3-diaminobenzidine (DAB) chromogen was obtained from Zytomed Systems (Berlin, Germany). Ki-67 immunoexpression was assessed using a commercial detection system (Ultra Vision Detection System; Lab Vision Corporation, Fremont, CA, USA).

Cell culture conditions. Experiments were accomplished using the T24 muscle invasive urinary bladder cancer cell line and the 5637 nonmuscle invasive urinary bladder cancer cell line. T24 cell line was provided by DSMZ (Düsseldorf, Germany); 5637 cell line was kindly provided by Dr. Paula Videira of the Nova University of Lisbon, Lisbon, Portugal. Both cell lines were cultured as a monolayer at $37^{\circ} \mathrm{C}$ and $5 \% \mathrm{CO}_{2}$ in RPMI-640 culture medium, supplemented with $10 \%$ heat-inactivated fetal bovine serum, $2 \mathrm{mM} \mathrm{L}$-glutamine and antibiotics (100 U/ml penicillin and $100 \mu \mathrm{g} / \mathrm{ml}$ streptomycin).

Carboplatin and piroxicam exposure. Urinary bladder cancer cell lines were treated with graded concentrations of carboplatin $(0.05$, 0.5 and $1 \mu \mathrm{M})$ and piroxicam $(167,333$ and $500 \mu \mathrm{M})$ for $72 \mathrm{~h}$ to assess dose-response profiles. For the combination approach, 0.05 $\mu \mathrm{M}$ of carboplatin was used with $333 \mu \mathrm{M}$ piroxicam. Both drugs were freshly prepared before each experiment. An untreated control group (cells not exposed to carboplatin and piroxicam) was used for all assays.

MTT assay. The MTT assay was used to assess the relative percentage of metabolically active cells compared to untreated cells. In brief, trypsinized $\mathrm{T} 24$ and 5637 cells were resuspended in a medium at $2 \times 10^{4}$ cells $/ \mathrm{ml}$. One hundred microliters of cell suspension was seeded in a 96-well culture plate (Sarstedt, Newton, $\mathrm{NC}, \mathrm{USA}$ ) and plates were incubated for $24 \mathrm{~h}$ to allow adherent cell growth. After overnight incubation, the medium was removed and the different agent solutions in medium were distributed to each well. After $72 \mathrm{~h}$ of incubation, $10 \mu \mathrm{l}$ MTT dye working solution (5 $\mathrm{mg} / \mathrm{ml}$ ) was added to each well and $4 \mathrm{~h}$ later the supernatant in the wells was removed and replaced by $100 \mu \mathrm{l} /$ well of dimethylsulfoxide. The absorbance values (A) of each well were recorded at $492 \mathrm{~nm}$ on an automatic ELISA plate reader (Multiskan EX; LabSystems, Helsinki, Finalnd). The percentage cell viability was calculated as: $\mathrm{A}_{\text {experimental group }} / \mathrm{A}_{\text {control }} \times 100$ (13).

Inverted light microscopy. An inverted light microscope (Axiovert 25; Carl Zeiss, Oberkochen, Germany) was used to analyze the effects of carboplatin and piroxicam, in isolation or combined, on cell confluence and appearance.

Drug combination studies. For the study of synergism between carboplatin and piroxicam in inhibition of T24 and 5637 cell growth, a combination index (CI) was determined using the data obtained from MTT assay. Drug combination studies were based on dose-effect curves generated as a plot of the fraction of unaffected cells versus drug concentration, in accordance to the method of Chou and Talalay (22), using the CI equation: $\mathrm{CI}=(\mathrm{D})_{1} /(\mathrm{Dx})_{1}+$ $(\mathrm{D})_{2} /(\mathrm{Dx})_{2}+(\mathrm{D})_{1}(\mathrm{D})_{2} /(\mathrm{Dx})_{1}(\mathrm{Dx})_{2}$, where $(\mathrm{D})_{1}$ and $(\mathrm{D})_{2}$ were the doses of carboplatin and piroxicam that exhibited a determined effect when applied simultaneously to the cells, and (Dx) $)_{1}$ and $(\mathrm{Dx})_{2}$ were the doses of the same drugs that exhibit the same determined effect when used in isolation. The inhibition of cell proliferation through combined treatment using carboplatin and piroxicam was represented by the fraction affected. The CI values indicates a synergistic effect when $<1$, an antagonistic effect when $>1$, and an additive effect when equal to 1 .

Leishman staining. Urinary bladder cancer cell lines $\left(2 \times 10^{4}\right.$ cells $/ \mathrm{ml}$ ) were cultured in the presence of carboplatin and piroxicam, in isolation or combined as described above. After incubation, cells were washed twice with phosphate-buffered saline (PBS) $\left(\mathrm{pH} \mathrm{7.4,} \mathrm{previously} \mathrm{heated} \mathrm{at} 37^{\circ} \mathrm{C}\right)$, fixed in methanol for 20 min at room temperature, washed once more with PBS, and stained with Leishman dye for $30 \mathrm{~min}$ (13). Slides were observed with a light microscope (Leica, Wetzlar, Germany) in order to detect morphological alterations.

Immunocytochemistry. Immunocytochemical assay was carried out in order to determine the expression of $\mathrm{Ki}-67$, a nuclear protein that is expressed in proliferating cells (24). Cells were plated in 24-well chamber slides (Sarstedt, Newton, NC, USA) and incubated overnight. Carboplatin and piroxicam were applied in isolation or combined for $72 \mathrm{~h}$. After being washed with PBS, cells were fixed with $4 \%$ paraformaldehyde for $15 \mathrm{~min}$ at room temperature and washed three times in an isotonic PBS buffer. Permeabilization was carried out using $1 \%$ Triton X-100 in PBS for $20 \mathrm{~min}$ at room temperature, and internal peroxidase activity was blocked with $3 \%$ hydrogen peroxide for $30 \mathrm{~min}$. Cells were incubated with primary antibody for Ki-67 (MIB-1, 1:100, Dako, Glostrup, Denmark) for $1 \mathrm{~h}$ at room temperature. After incubation with the secondary antibody, positive immunoreactivity was visible by means of the reaction of $\mathrm{DAB}$. The samples were washed with water and 
$\mathbf{A}$
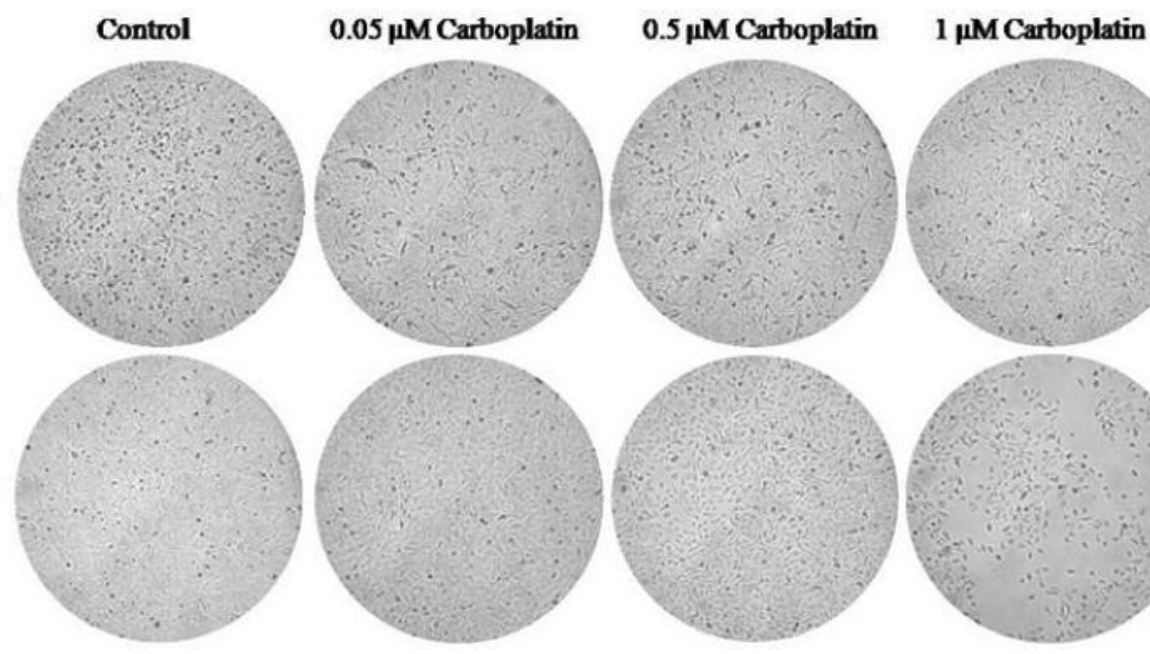

T24
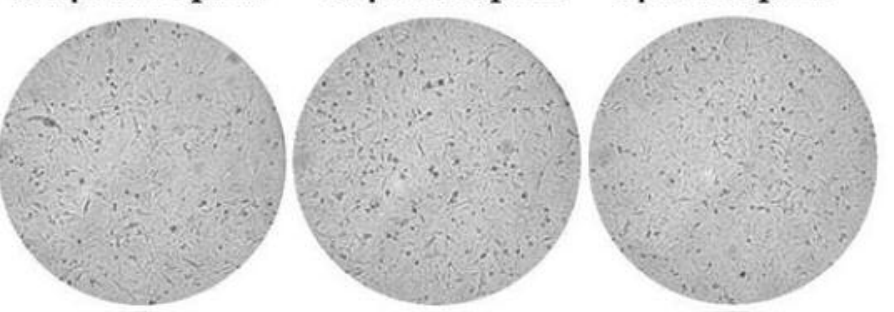

5637
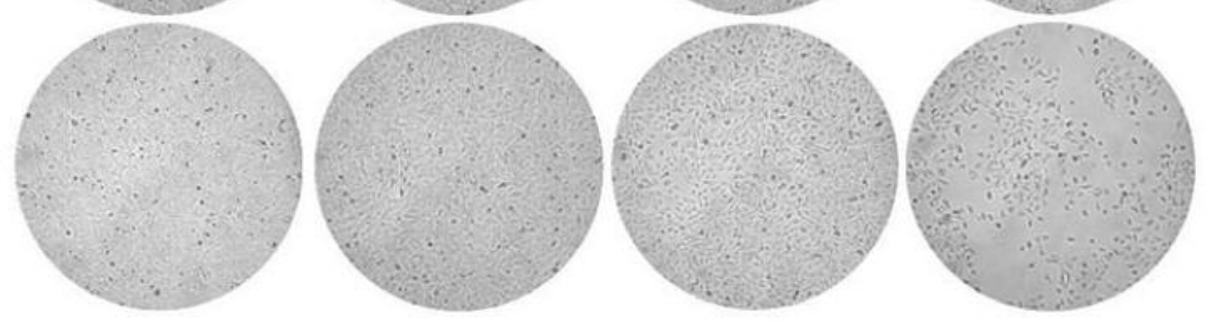

$\mathbf{B}$
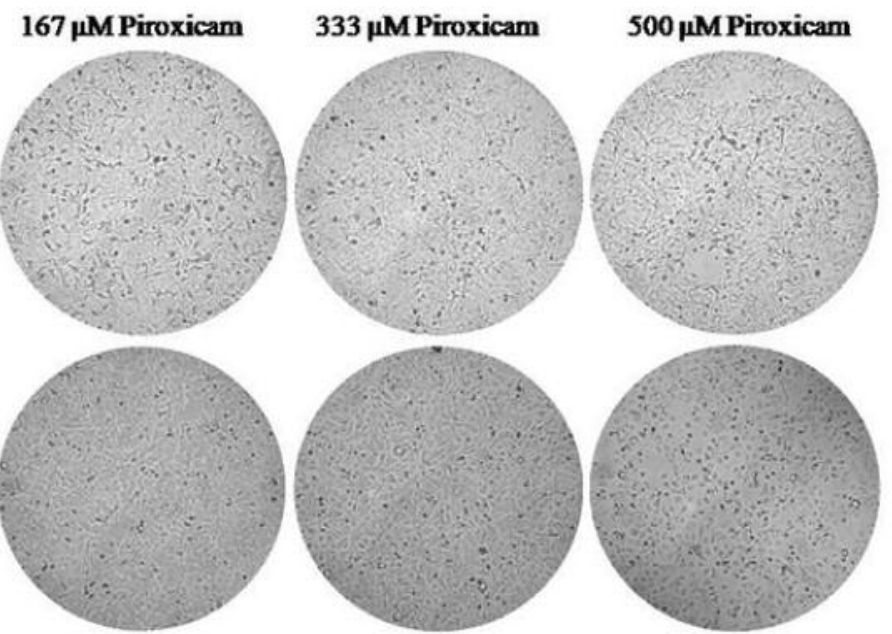

Figure 1. Urinary bladder cancer cell line culture observed under an inverted light microscope. T24 and 5637 cells in the absence (control) or in the presence of carboplatin $(A)$ and piroxicam $(B)$.

contrasted with hematoxylin. Negative controls were performed by replacing primary antibody with PBS (23). Samples were analyzed qualitatively with a Leica microscope (Wetzlar, Germany).

Terminal deoxynucleotidyl transferase-mediated dUTP nick end labelling assay (TUNEL). Cells $\left(2 \times 10^{4}\right.$ cells $\left./ \mathrm{ml}\right)$ were seeded and allowed to attach overnight. After treatment with carboplatin and piroxicam for $72 \mathrm{~h}$, in isolation or combined, apoptosis was detected by means of the Fluorescein In Situ Cell Death Detection Kit, in accordance with the manufacturer's instructions. In brief, cell nuclei were counterstained with 4',6-diamidino-2-phenylindole and fragmentation was detected by its turning into a green color. Positive (cells incubated with DNase I recombinant) and negative (cells incubated with all reagents except TdT) controls were included in each experiment. Slides were observed using a fluorescence microscope (Nikon Eclipse E400; Nikon Tokyo, Japan). For each slide, 200 cells were counted in random fields to assess the number of cells undergoing apoptosis. Cells with positively labelled (green color) nuclear area were considered apoptotic. The apoptotic index $(\%)$ was defined as: (number of apoptotic cells/total number of cells) $\times 100(23)$.

Monodansylcadaverine (MDC) staining. Autophagic vacuoles induced by carboplatin and piroxicam were evaluated using the auto-fluorescent substance MDC. Cells were seeded in a glass coverslip $(8 \mathrm{~mm})$, cultured for $24 \mathrm{~h}$ and treated with drugs, in isolation or combined, for $72 \mathrm{~h}$. The medium was removed and MDC (Sigma Aldrich) was added to the cells at $25 \mu \mathrm{M}$, at $37^{\circ} \mathrm{C}$ and for $1 \mathrm{~h}$. Subsequently, cells were washed three times with PBS and immediately analyzed using a fluorescence microscope (Nikon Eclipse E400; Nikon).

Statistical analysis. Statistical analysis was carried out using SPSS 17.0 statistical software (SPSS Inc., Chicago, IL, USA). The 

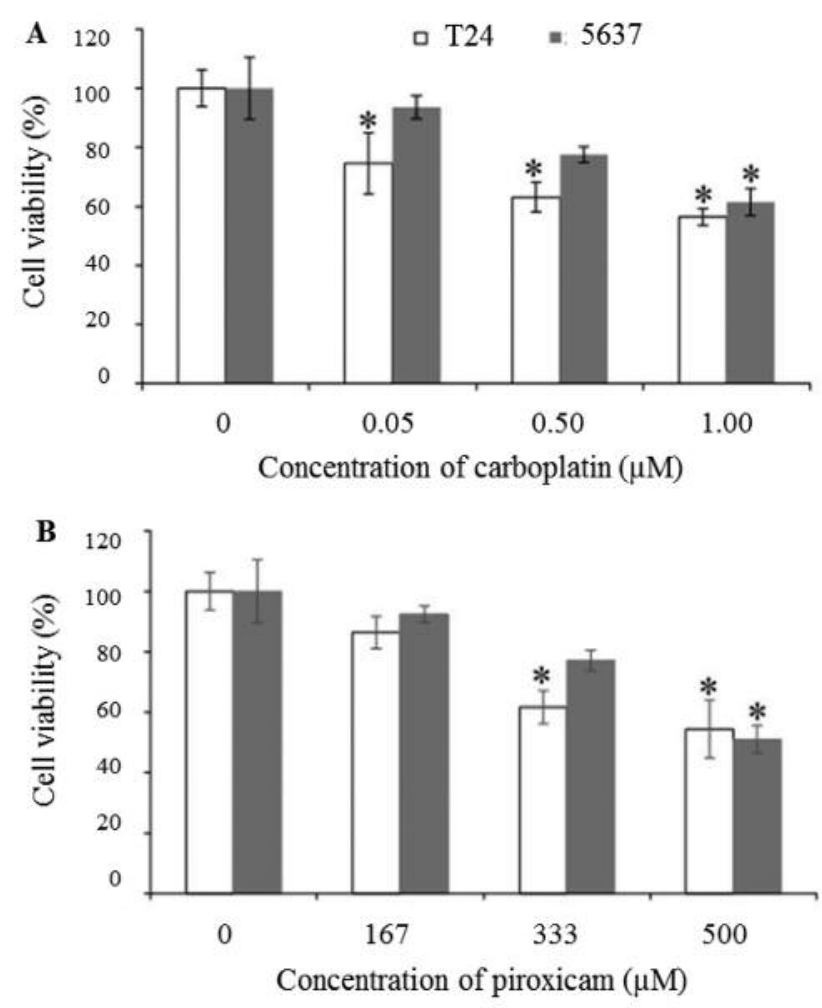

Figure 2. Evaluation of cell viability in T24 and 5637 urinary bladder cancer cell lines, assessed by the 3-(4,5-dimethyl-2-thiazolyl)-2,5diphenyltetrazolium bromide assay, after $72 \mathrm{~h}$ of exposure to single-drug carboplatin (A) and piroxicam (B). The data represent the mean values \pm standard deviation. ${ }^{*} p<0.05$ versus untreated cells.

equality of variances was tested by Levene F-test and the statistical significance of differences between the treatment and control groups was determined by Dunnett's multiple comparison post-hoc test for the MTT assay. $p$-Values of less than 0.05 were considered to be statistically significant.

\section{Results}

Cell confluence after treatment with carboplatin and piroxicam. The T24 and the 5637 cells were exposed to carboplatin $(0.05,0.5$ and $1 \mu \mathrm{M})$ and piroxicam $(167,333$ and $500 \mu \mathrm{M})$, in isolation for $72 \mathrm{~h}$. Cells were analyzed under an inverted light microscope. The surface of the cell layer in control flasks was confluent with visible cells undergoing division. A decrease in cell population was observed with increasing doses of both drugs when compared with untreated cells. A marked decrease in the cell population was observed at $1 \mu \mathrm{M}$ carboplatin and $500 \mu \mathrm{M}$ piroxicam in the 5637 cell line (Figure 1).

Isolated effects of carboplatin and piroxicam on cell viability. At the exponential growth phases, both T24 and the
5637 urinary bladder cancer cell lines were exposed to different concentrations of carboplatin and piroxicam, in isolation, and the effect on cell viability was examined after $72 \mathrm{~h}$ of culture by the MTT assay (Figure 2). The single-drug exposure to carboplatin and piroxicam reduced cell viability in both cell lines in a dose-dependent manner. At $1 \mu \mathrm{M}$ carboplatin, cell viability rates of $56.0 \%$ and $61.0 \%$ were obtained in T24 $\left(p=5.7 \times 10^{-8}\right)$ and $5637\left(p=1.4 \times 10^{-4}\right)$ cells, respectively (Figure $2 \mathrm{~A}$ ). At $500 \mu \mathrm{M}$ piroxicam, cell viability rates of $54.0 \%$ and $51.0 \%$ were recorded for T24 $\left(p=5.1 \times 10^{-6}\right)$ and $5637\left(p=4.4 \times 10^{-6}\right)$ cells, respectively (Figure 2B).

Combined effects of carboplatin and piroxicam on cell viability. The simultaneous exposure of T24 and 5637 cells to carboplatin $(0.05,0.5$ and $1 \mu \mathrm{M})$ and piroxicam $(167,333$ and $500 \mu \mathrm{M})$ reduced the cell viability rate in both cell lines when compared with each drug in isolation (Figure 3 ). When compared to the T24 cell line, the 5637 cell line was more sensitive to drugs used in combination, even at the lowest carboplatin concentration tested $(0.05 \mu \mathrm{M})$ with 167,333 and $500 \mu \mathrm{M}$ of piroxicam. All the combinations were statistically significantly effective when compared with the control group $(p<0.05)$.

Combination index. In order to analyze the type of interaction (synergic, additive, or antagonistic) between the carboplatin and piroxicam in combination on T24 and 5637 cell lines, we implemented the method developed by Chou and Talalay on MATLAB (22) to determine the $\mathrm{CI}_{50}$ values. The $50 \%$ dose reduction index $\left(\mathrm{DRI}_{50}\right)$ represents the magnitude of dose reduction obtained for the $50 \%$ growthinhibitory effect in combination as compared to each drug alone. The $\mathrm{CI}_{50}$ and $\mathrm{DRI}_{50}$ for carboplatin and piroxicam are shown in Table I. The results demonstrated that a synergistic interaction on cell viability of both cell lines was observed when the two drugs were used concomitantly.

Morphological changes. Incubation with carboplatin and piroxicam led to marked alterations in T24 and 5637 cell morphology, namely the presence of apoptotic cells and apoptotic bodies. These morphological alterations were more frequent when cells were treated with both drugs in combination. Untreated cells showed morphology consistent with cells undergoing division (Figure 4).

Cell proliferation. Immunocytochemistry was carried out in order to evaluate Ki-67 expression in the two cell lines exposed to carboplatin $(0.05 \mu \mathrm{M})$ and piroxicam $(333 \mu \mathrm{M})$, in isolation and when combined. Positive controls significantly expressed Ki-67, while a moderate expression was observed in cells exposed to carboplatin or piroxicam. The combined approach using both carboplatin and 

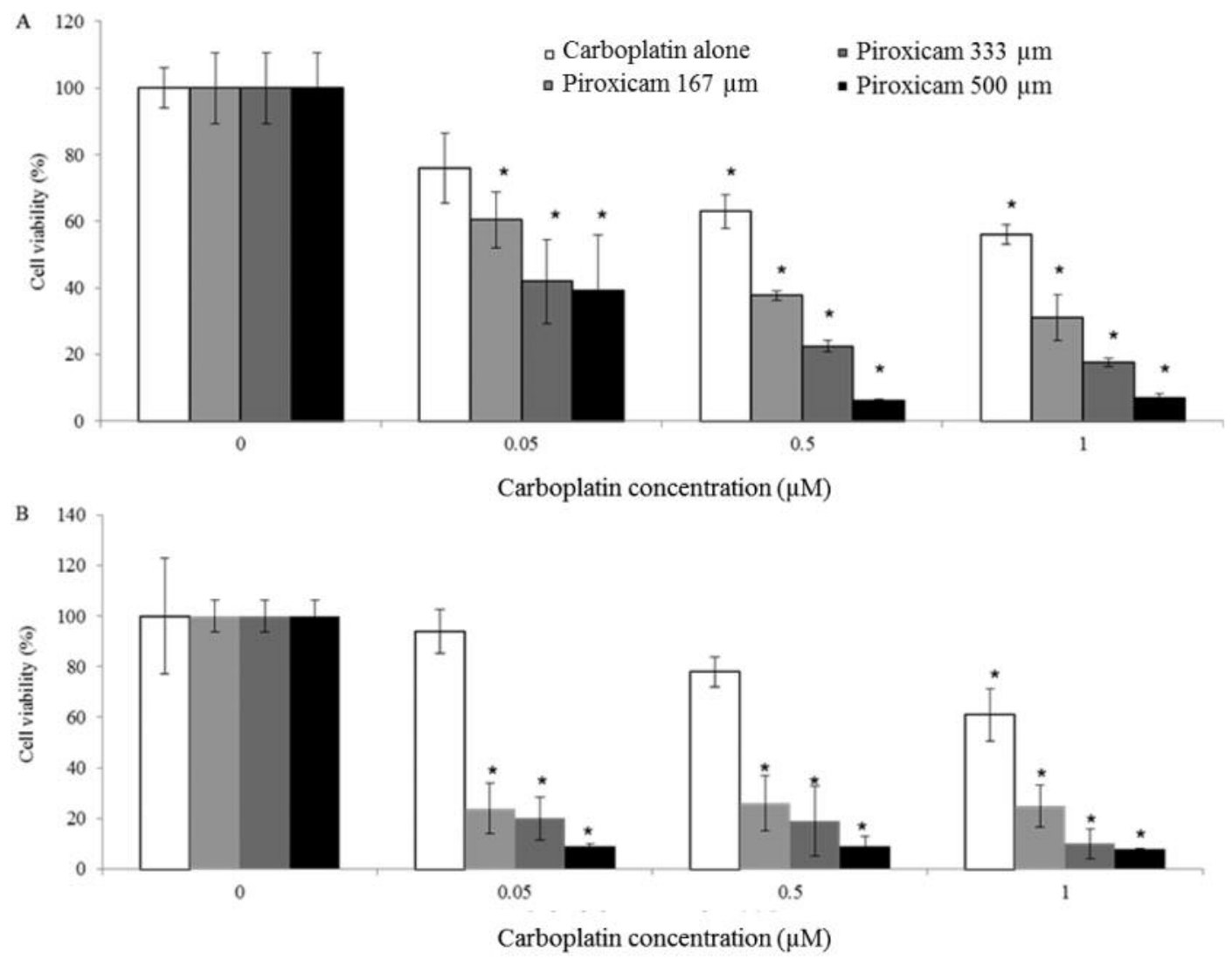

Figure 3. Combined effects of carboplatin and piroxicam in $T 24(A)$ and 5637 (B) urinary bladder cancer cell lines, assessed by using the 3-(4,5dimethyl-2-thiazolyl)-2,5-diphenyltetrazolium bromide assay. The data represent the mean values \pm standard deviation. ${ }^{*} p<0.05$ versus untreated cells.

Table I. Combination index $(C I)$ and dose reduction index (DRI) values for carboplatin and piroxicam combination. The CI $I_{50}$ is a combination index for 50\% effect, used for qualifying synergism, additivity and antagonism.

\begin{tabular}{lccccc}
\hline & Carboplatin $\left(\mathrm{CI}_{50} \mu \mathrm{M}\right)$ & Piroxicam $\left(\mathrm{CI}_{50} \mu \mathrm{M}\right)$ & $\mathrm{CI}_{50}$ & DRI $_{50}$ & Interpretation \\
\hline $\mathrm{T} 24$ & 1 & 500 & 0.65 & Carboplatin: 20 & Synergism \\
5637 & 1 & 500 & 0.17 & $\begin{array}{c}\text { Piroxicam: } 1.8 \\
\text { Carboplatin: } 20\end{array}$ & Synergism \\
& & & & Piroxicam: 8.6 & \\
\hline
\end{tabular}

Table II. Ki-67 immunocytochemical expression on T24 and 5637 urinary bladder cancer cell lines treated with carboplatin and piroxicam, alone and in combination.

\begin{tabular}{lccccc}
\hline & Positive control & Negative control & $0.05 \mu \mathrm{M}$ Carboplatin & $333 \mu \mathrm{M}$ Piroxicam & $0.05 \mu \mathrm{M}$ Carboplatin $+333 \mu \mathrm{M}$ piroxicam \\
\hline T24 & ++++ & - & +++ & +++ & ++ \\
5637 & ++++ & - & +++ & +++ & ++ \\
\hline
\end{tabular}

- No staining; + very weak staining; ++ weak staining; +++ moderate or intense staining; ++++ highest intensity staining.

piroxicam not only reduced the density of cells per microscopic field, but also the Ki-67 expression in those cell lines (Table II).
Apoptosis. Most nuclei were undamaged in untreated T24 and 5637 cells. Cells treated with piroxicam presented a lower degree of apoptosis in the T24 cell line and a higher 


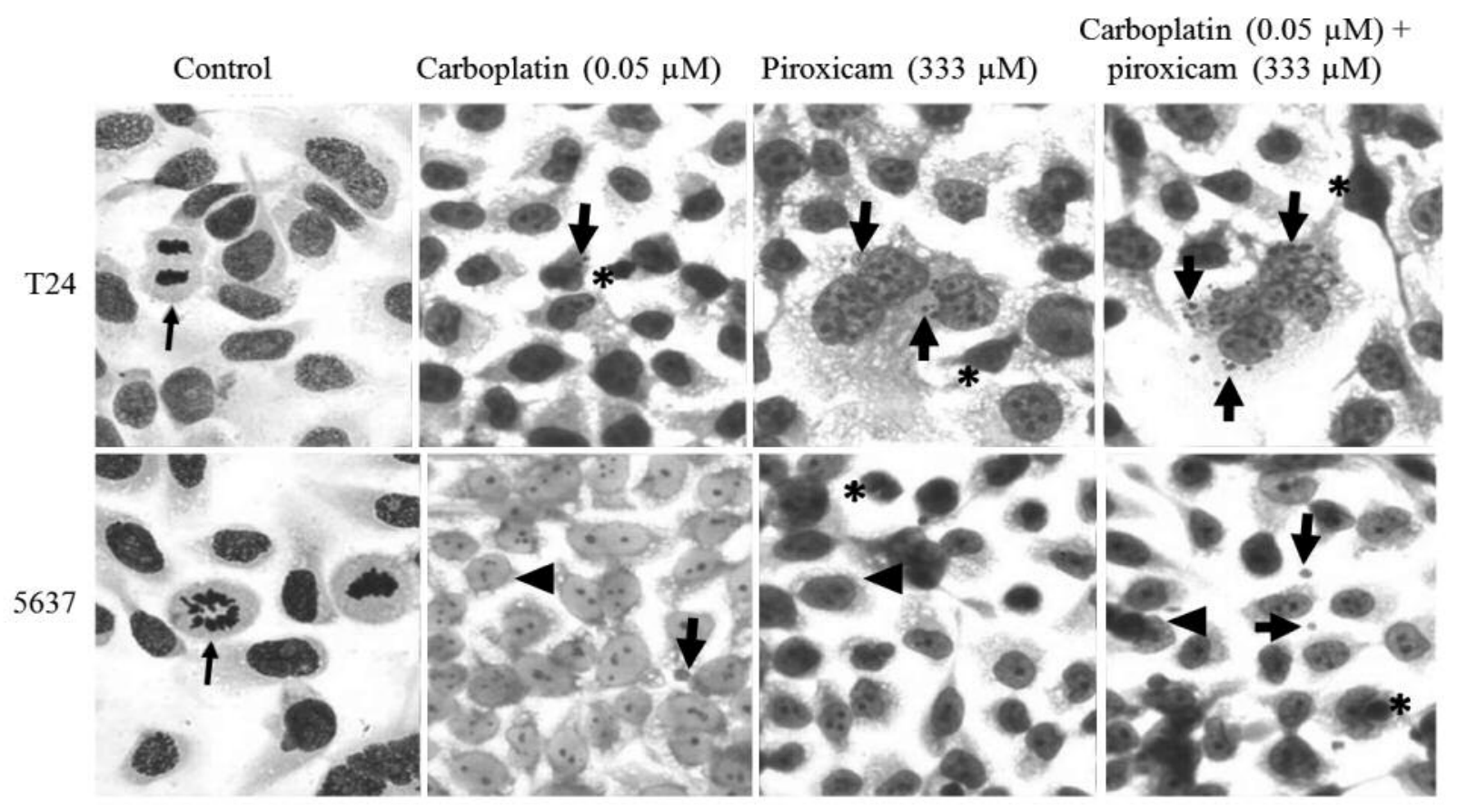

Figure 4. Effects of carboplatin and piroxicam, alone and in combination, on T24 and 5637 cell morphology. Untreated control cells presented morphological features of dividing cells (arrow). Carboplatin and piroxicam-treated cells exhibited apoptotic bodies (black arrow), apoptotic cells (asterisk) and vacuolated cytoplasm (triangle). Original magnification $\times 1000$.

degree in the 5637 cell line when compared to carboplatin effects. With the combination treatment, a minor increase of apoptotic cells was found in T24 and 5637 cell lines by the TUNEL assay, however, this effect did not lead to statistically different findings from those of the other treatments and control (Figure 5).

Autophagy. MDC staining allowed the visualization of mature autophagic vacuoles. No autophagic vacuoles were observed in untreated cells. MDC-labelled vacuoles were observed with single treatment with carboplatin or piroxicam in both urinary bladder cancer cell lines. An increased number of MDC-labelled vacuoles were detected in cytoplasm and perinuclear regions of both cell lines when carboplatin and piroxicam were combined (Figure 6).

\section{Discussion}

Preclinical models play a crucial role in the development of novel targeted-therapies required to further improve the effectiveness of urinary bladder cancer chemotherapy (13). Urinary bladder cancer cell lines have been invaluable research tools for evaluating the efficacy of new drugs (13, 24). In the present study, it was investigated whether piroxicam could strengthen carboplatin efficacy, using in vitro

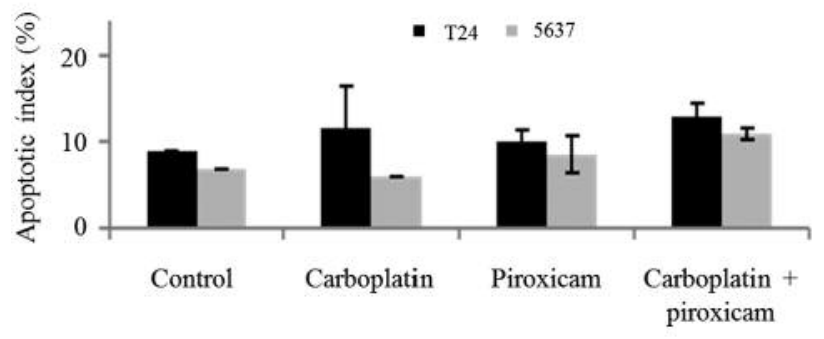

Figure 5. Percentage of apoptotic cells determined by terminal deoxynucleotidyl transferase-mediated dUTP nick-end labeling assay in T24 and 5637 urinary bladder cancer cell lines after exposure to $0.05 \mu \mathrm{M}$ carboplatin and $333 \mu \mathrm{M}$ piroxicam, alone and in combination. No statistical differences were found.

models of two human urinary bladder cancer cell lines. According to Pinto-Leite and collaborators, these two cell lines cover the most frequent subtypes of urinary bladder cancer; the T24 cell line represents a subtype of fibroblast growth factor receptor 3 (FGFR3)/cyclin D1 (CCND1), while the 5637 cell line represents the E2F transcription factor 3 (E2F3)/retinoblastoma 1 (RB1) circuit mutational profile, with the former representing a less aggressive phenotype and the latter bearing more invasive and metastatic properties (24). 


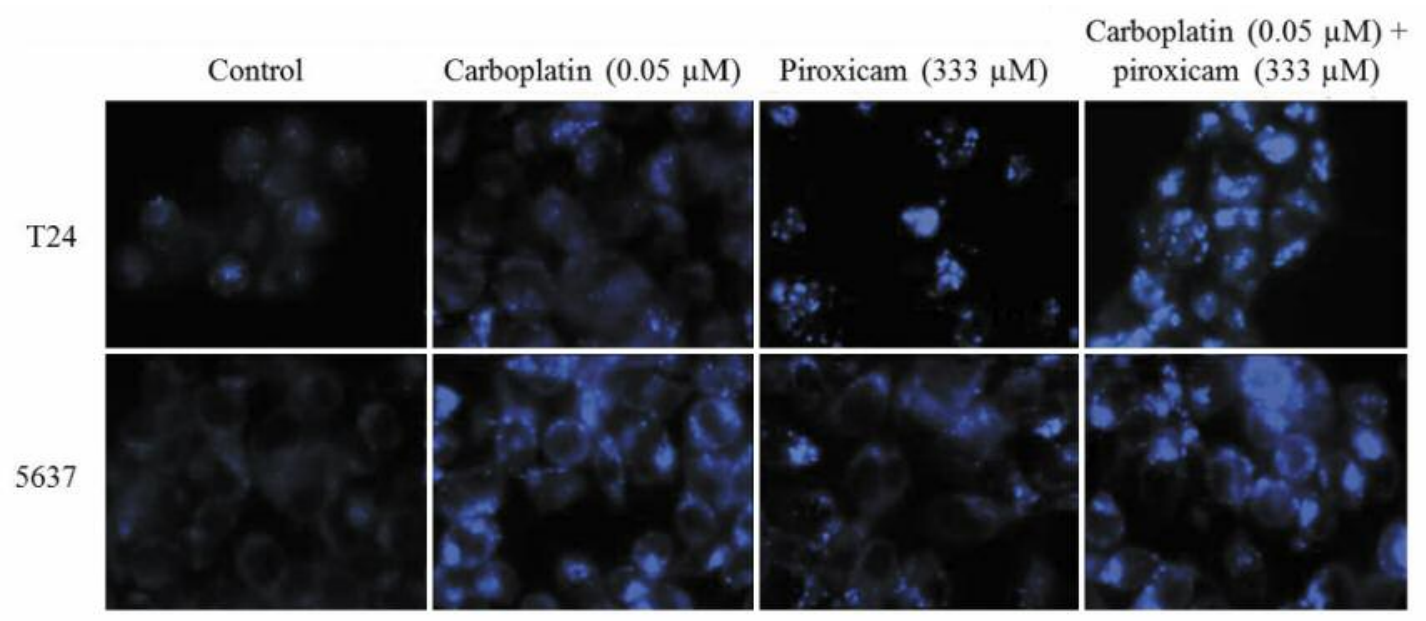

Figure 6. Fluorescence images obtained from T24 and 5637 cells exposed to carboplatin and piroxicam, alone and in combination. Autophagosomes are pictured as distinct dot-like fluorescent structures. Original magnification $\times 200$.

In this study, two drugs with different mechanism of action were used. Carboplatin is an anti-neoplastic drug applied in patients with impaired renal function (25) for the treatment of urothelial and metastatic carcinomas (26-29). Indeed, its use is associated with fewer side-effects when compared with cisplatin, which is considered the backbone of urinary bladder cancer treatment (30). According to Mohammed et al., the prescription of COX inhibitors in patients with urinary bladder cancer leads to the increase of the remission period, extending the lifespan and the patients' quality of life (31).

To date, the combination of carboplatin and piroxicam was only investigated in two different types of carcinomas in dogs. Boria and collaborators evaluated carboplatin and piroxicam therapy in dogs with transitional urinary bladder carcinoma and observed a remission rate of $40 \%$, providing evidence that this $\mathrm{COX}$ inhibitor enhances the antitumor activity of carboplatin (32). The other investigation was carried out in a canine model of human head and neck squamous cell carcinoma where this multi-agent protocol was well tolerated and resulted in a complete regression of tumor without additional surgery in $57 \%$ of the cases (33). Despite these promising results, there are no studies regarding the effectiveness of the simultaneous use of these two drugs in human urinary bladder cancer cell lines.

In this study, we investigated the effectiveness of carboplatin and piroxicam combination on cell viability, cell proliferation, morphological changes, apoptosis and autophagy of two human urinary bladder cancer cell lines. After $72 \mathrm{~h}$ of treatment with both drugs, a synergistic effect was obtained in the T24 and 5637 cell lines, with a CI of less than 1 . The use of several drugs with different mechanisms or means of action may treat a disease more effectively. The possible favorable outcomes for synergism include: increasing the efficacy of the therapy, reducing the dose while increasing or maintaining the same efficacy thereby reducing/avoiding toxicity, minimizing or slowing down the development of drug resistance, and providing selective synergism against the target (or efficacy synergism) versus host (or toxicity antagonism). Because of these therapeutic benefits, drug combinations have been widely used and have become the leading choice for treating the most dreadful diseases, such as cancer (34).

The synergistic interaction observed between carboplatin and piroxicam was confirmed by the use of other biological approaches. When associated with a decrease in cell viability and proliferation, there was an increase in cell death by autophagy or apoptosis. Apoptosis is considered a pathway with a specific morphological pattern of programmed death (35). It was found that piroxicam in isolation induced a slight increase of apoptosis in both cell lines when compared to untreated cells. Similar results were presented in canine head and neck squamous carcinoma cells (33) and in mesothelioma cell lines (36). The combination of both drugs induced a minimal increase in the number of apoptotic cells in both cell lines compared to the use of the drugs in isolation. Baldi and collaborators also found a minor increase in the apoptotic index when piroxicam and cisplatin were used simultaneously (36). Recently, autophagy has been associated with a genetically programmed pathway that promotes cell death and with an important effect on cancer $(37,38)$. Munafó and Colombo introduced MDC staining as a marker to detect autophagy (39). In this study, piroxicam in combination with carboplatin had an enhancing effect, with a marked increase of labelled vacuoles.

In summary, our data demonstrate that carboplatin and piroxicam have biological activity against human urinary 
bladder cancer cell lines and their activity is synergistic when administered simultaneously. Taking into account the expertise of our research group in in vivo cancer models, the next step will be the evaluation of the efficacy of this combination in animal models of papilar and invasive urothelial carcinomas in rats and mice, respectively.

\section{Conflicts of Interests}

None to declare.

\section{Acknowledgements}

This work was supported by European Investment Funds by FEDER/COMPETE/POCI - Operational Competitiveness and Internationalization Programme, under the Project POCI-01-0145FEDER-006958 and the project POCI-01-0145-FEDER-016728, and Portuguese Science and Technology Foundation (FCT), under the project UID/AGR/04033/2013, the project PTDC/DES/ $114122 / 2009$, the project PTDC/DTP-DES/6077/2014, and postgraduation grants SFRH/BD/102099/2014 and SFRH/BPD/ 101700/2014.

The Authors express their deepest appreciation to Professor Ana Maria Nazaré Pereira of the University of Trás-os-Montes and Alto Douro for the availability of the ELISA reader.

\section{References}

1 Radosavljevic V and Belojevic G: Shortcomings in ladder cancer etiology research and a model for its prevention. Tumori 100(1): $1-8,2014$.

2 Skeldon AM, Faraj $M$ and Saleh $M$ : Caspases and inflammasomes in metabolic inflammation. Immunol Cell Biol 92: 304-313, 2014.

3 Tanaka T, Miyazawa K, Tsukamoto T, Kuno T and Suzuki K: Pathobiology and chemoprevention of bladder cancer. J Oncol http://doi.org/10.1155/2011/528353, 2011.

4 Dash A, Galsky MD, Vickers AJ, Serio AM, Koppie TM, Dalbagni $G$ and Bochner BH: Impact of renal impairment on eligibility for adjuvant cisplatin-based chemotherapy in patients with urothelial carcinoma of the bladder. Cancer 107(3): 506513, 2006.

5 Balducci L: Evidence-based management of cancer in the elderly. Cancer Control 7(4): 368-376, 2000.

6 De Santis M and Bachner M: New developments in first- and second-line chemotherapy for transitional cell, squamous cell and adenocarcinoma of the bladder. Curr Opin Urol 17(5): 363368, 2007.

7 Piccart MJ, Lamb $\mathrm{H}$ and Vermorken JB: Current and future potential roles of the platinum drugs in the treatment of ovarian cancer. Ann Oncol 12(9): 1195-1203, 2001.

8 McWhinney SR, Goldberg RM and McLeod HL: Platinum neurotoxicity pharmacogenetics. Mol Cancer Therapeut 8(1): 1016, 2009.

9 Iwasaki K, Obara W, Kato Y, Takata E, Tanji S and Fujioka T: Neoadjuvant gemcitabine plus carboplatin for locally advanced bladder cancer. J Clin Oncol 43(2): 193-199, 2013.
10 Mizutani Y, Nakanishi H, Li YN, Sato N, Kawauchi A and Miki T: Enhanced sensitivity of bladder cancer cells to cisplatin mediates cytotoxicity and apoptosis in vitro and in vivo by the selective ciclooxigenase-2 inhibitor JTE-522. J Urol 172(4): 1474-1479, 2004.

11 Naruse T, Nishida Y and Ishiguro N: Synergistic effects of meloxicam and conventional cytotoxic drugs in human MG-63 osteosarcoma cells. Biomed Pharmacother 61(6): 338-346, 2007.

12 Arantes-Rodrigues R and Pinto-Leite R, Fidalgo-Gonçalves L, Gaivão I, Colaço A, Oliveira P and Santos L: Meloxicam synergistically enhances the in vitro effects of sunitinib malate on bladder cancer cells. J Appl Biomed 11(2): 79-92, 2013.

13 Arantes-Rodrigues R and Pinto-Leite R, Fidalgo-Gonçalves L, Palmeira C, Santos L, Colaço A and Oliveira P: Synergistic effect between cisplatin and sunitinib malate on human urinary bladder-cancer cell lines. Bio Med Res Int 2013: 11, 2013.

14 Steele VE, Hawk ET, Viner JL and Lubet RA: Mechanisms and applications of non-steroidal anti-inflammatory drugs in the chemoprevention of cancer. Mutat Res 523-524: 137-144, 2003.

15 Ustün Alkan F, Ustüner O, Bakirel T, Çinar S, Erten G and Deniz G: The effects of piroxicam and deracoxib and canine mammary tumour cell line. Sci Wld J 2012: 8, 2012.

16 Gupta S, Srivastava M, Ahmad N, Bostwick DG and Mukhtar $\mathrm{H}$ : Overexpression of cyclooxygenase-2 in human prostate adenocarcinoma. Prostate 42(1): 73-78, 2000.

17 Hwang D, Scollard D, Byrne J and Levine E: Expression of cyclooxygenase-1 and cyclooxygenase- 2 in human breast cancer. J Natl Cancer Inst 90(6): 455-460, 1998.

18 Mohammed SI, Craing BA, Mutsaers AJ, Glickman NW, Snyder PW, Gostari AE, Schlittlwe DL, Coffman KT, Bonney PL and Knapp DM: Effects of the cyclooxygenase inhibitor, piroxicam, in combination with chemotherapy on tumor response, apoptosis, and angiogenesis in a canine model of human invasive urinary bladder cancer. Mol Cancer Therapeut 2(2): 183-188, 2003.

19 Mohammed SI, Bennett PF, Craig BA, Glickman NW, Mutsaers AJ, Snyder PW, Widmer WR, DeGortari AE, Bonney PL and Knapp DW: Effects of the cyclooxygenase inhibitor, piroxicam, on tumor response, apoptosis, and angiogenesis in a canine model of human invasive urinary bladder cancer. Cancer Res 62(2): 356-358, 2002.

20 Souza CH, Toledo-Piza E and Amorin E, Barboza A and Tobias $\mathrm{KM}$ : Inflammatory mammary carcinoma in 12 dogs: clinical features, cyclooxygenase-2 expression, and response to piroxicam treatment. Can Vet J 50(5): 506-510, 2009.

21 Schmidt BR, Glickman NW, DeNicola DB, Gortari AE and Knapp DW: Evaluation of piroxicam for the treatment of oral squamous cell carcinoma in dogs. J Am Vet Med Assoc 218(11): 1783-1786, 2001.

22 Chou TC and Talalay P: Quantitative analysis of dose-effect relationships: the combined effects of multiple drugs or enzyme inhibitors. Adv Enzyme Reg 22: 27-55, 1984.

23 Pinto-Leite R and Arantes-Rodrigues R, Palmeira C, Colaço B, Lopes C, Colaço A, Costa C, Silva VM, Oliveira P and Santos L: Everolimus combined with cisplatin has a potential role in treatment of urothelial bladder cancer. Biomed Pharmacother 67(2): 116-121, 2013.

24 Pinto-Leite R and Carreira I, Melo J, Ferreira SI, Ribeiro I, Ferreira J, Filipe M, Bernardo C, Arantes-Rodrigues R, Oliveira $\mathrm{P}$ and Santos L: Genomic characterization of three urinary bladder cancer cell lines: understanding genomic types of urinary bladder cancer. Tumour Biol 35(5): 4599-4617, 2014. 
25 Yoneyama T, Tobisawa T, Yoneyama T, Yamamoto H, Imai A Hatakeyama S, Hashimoto $\mathrm{Y}$, Koie $\mathrm{T}$ and Ohyama C: Carboplatin-based combination chemotherapy for elderly patients with advanced bladder cancer. Int J Clin Oncol 20(2): 369-374, 2015.

26 Dogliotti L, Cartenì G, Siena S, Bertetto O, Martoni A, Bono A, Amadori D, Onat $\mathrm{H}$ and Marini L: Gemcitabine plus cisplatin versus gemcitabine plus carboplatin as first-line chemotherapy in advanced transitional cell carcinoma of the urothelium: results of a randomized phase 2 trial. Eur Urol 52(1): 134-141, 2007.

27 Dreicer R, Manola J, Roth BJ, See BA, Kuross S, Edelman MJ, Hudes GR and Wilding G: Phase III trial of methotrexate, vinblastine, doxorubicin, and cisplatin versus carboplatin and paclitaxel in patients with advanced carcinoma of the urothelium. Cancer 100(8): 1639-1645, 2004.

28 Hudson E and Lester JF: Gemcitabine and carboplatin in the treatment of transitional cell carcinoma of the urothelium: a single centre experience and review of the literature. Eur J Cancer Care 19(3): 324-328, 2010.

29 Park JH, Lee SW, Kim HS, Kang SG, Ko YH, Kim ST, Kang SH, Park YJ, Choi IK, Oh SC, Sung DJ, Seo JH, Cheon J, Kim YH, Kim JS and Park KH: Combination of gemcitabine and carboplatin as first line treatment in elderly patients or those unfit for cisplatin-based chemotherapy with advanced transitional cell carcinoma of the urinary tract. Cancer Chemother Pharmacol 71(4): 1033-1039, 2013.

30 Etienne MC, Leger F, Pivot X, Chatelut E, Bensadoun RJ, Guardiola E, Renée N, Magné N, Canal P and Milano G: Pharmacokinetics of low-dose carboplatin and applicability of a method of calculation for estimating individual drug clearance. Ann Oncol 14(4): 643-647, 2003.

31 Mohammed SI, Dhawan D, Abraham S, Snyder PW, Waters DJ, Craig BA, Lu M, Wu L, Zheng R, Stewart J and Knapp DW: Cyclooxygenase inhibitors in urinary bladder cancer: in vitro and in vivo effects. Mol Cancer Therapeut 5(2): 329-336, 2006.
32 Boria PA, Glickman NW, Schmidt BR, Widmer WR, Mutsaers AJ, Adams LG, Snyder PW, DiBernardi L, de Gortari AE, Bonney PL and Knapp DW: Carboplatin and piroxicam therapy in $31 \mathrm{dogs}$ with transitional cell carcinoma of the urinary bladder. Vet Compar Oncol 3(2): 73-80, 2005.

33 Vos JP, Burm AG, Focker AP, Boschloo H, Karsijns M, van der Waal I: Piroxicam and carboplatin as a combination treatment of canine oral non-tonsillar squamous cell carcinoma: a pilot study and a literature review of a canine model of human head and neck squamous cell carcinoma. Vet Compar Oncol 3(1): 16-24, 2005.

34 Chou TC: Theoretical basis, experimental design and computerized simulation of synergism and antagonism in drug combination studies. Pharmacol Rev 58(3): 621-281, 2006.

35 Fink SL and Cookson TC: Apoptosis, pyroptosis, and necrosis: mechanistic description of dead and dying eukaryotic cells. Infection and Immunity 73(4): 1907-1916, 2005.

36 Baldi A, Piccolo MT, Boccellino MR, Donizetti A, cardillo I, La Porta R, Quagliuolo L, Spugnini EP, Cordero F, Citro G, Menegozzo M, Calogero RS and Crispi S: Apoptosis induced by piroxicam plus cisplatin combined treatment is triggered by $\mathrm{p} 21$ in mesothelioma. PLoS One 6(8): e23569, 2011.

37 Cuervo AM: Autophagy: in sickness and in health. Trend Cell Biol 14(2): 70-77, 2004.

38 Kondo Y, Kanzawa T, Sawaya R and Kondo S: The role of autophagy in cancer development and response to therapy. Nat Rev Cancer 5(9): 726-734, 2005.

39 Munafó DB and Colombo MI: A novel assay to study autophagy: regulation of autophagosome vacuole size by amino acid deprivation. J Cell Sci 114(20): 3619-3629, 2001.

Received February 13, 2017 Revised March 9, 2017 Accepted March 13, 2017 